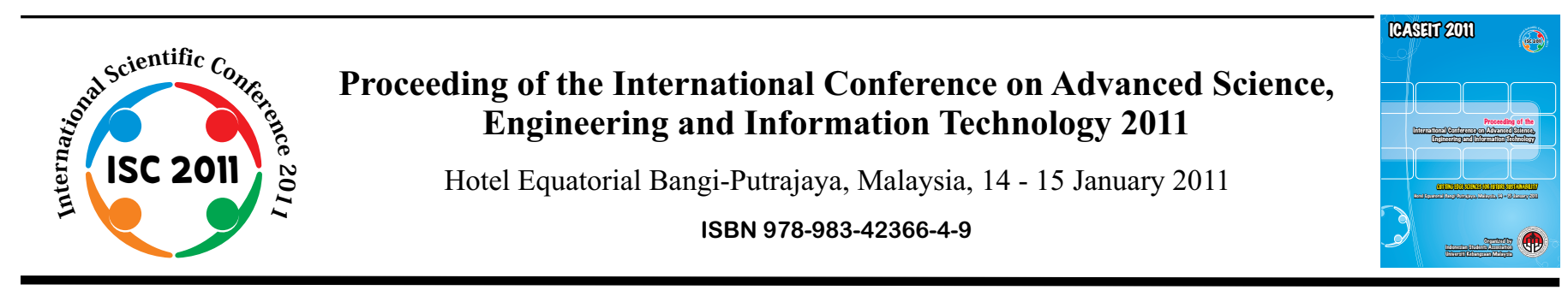

\title{
Possibility of Lime as a Stabilizer in Compressed Earth Brick (CEB)
}

\author{
Fetra Venny Riza ${ }^{1}$, Ismail Abdul Rahman ${ }^{1}$, Ahmad Mujahid Ahmad Zaidi ${ }^{2}$ \\ ${ }^{1}$ Faculty of Civil and Environmental Engineerin, UTHM \\ Parit Raja, 86400, Johor, Malaysia \\ Tel.:+60142468038, E-mail: fetravenny@gmail.com \\ ${ }^{2}$ Faculty of Mechanical and Manufacturing Engineering, UTHM \\ Parit Raja, 86400, Johor, Malaysia \\ Tel.:+6017478139, E-mail: mujahid@uthm.edu.myz
}

\begin{abstract}
This paper highlights the production of lime, chemical reaction during the production process, lime reaction with the soil and the prospective use of lime in the future. The research works that has been carried out showed lime has superior properties than cement in enhancing soil structure and also exhibits less embodied energy than cement. The lime through its chemical composition, calcium hydroxide, able to reacts with the pozzolanic materials that presents in the clay soil. This pozzolanic reaction resulted to the formation C-S-H cementitious gel that will further stabilize the soil. The application of lime will also promote healthier environment since carbonation process that occur during carbonation period absorb carbon dioxide in the air. The production of compressed stabilized earth brick using lime will also contributes to greener environment as compared to normal brick production method which consumed extensive energy.
\end{abstract}

Keywords — Lime, hydraulic, hydrated, pozzolanic, clay.

\section{INTRODUCTION}

The earliest used of lime can be traced back to 4000 B.C. when it was used in Egypt for constructing pyramids [1]. The Egyptian utilized gypsum (calcium sulfate) mortars to lubricate the beds of large stones when they were being moved into position [2]. First documentation on the usage of lime in construction on road stabilization was during the Roman Empire. The document was written by Marcus Vitruvius Pollio (80 BC $-15 \mathrm{BC})$ an architect, engineer and writer, and known as the world first known engineer [3]. Lime has proven performances and played important role in masonry construction which has lasted for centuries such as Great Wall of China.

Originally, construction materials beside stone and metal were made up from mud or clay because its availability and low cost, but these materials have poor performance in the presence of water and high level humidity. Then it was discovered that limestone when burnt and combined with water created material that harden with age. Roman people were the pioneers in applying pozzolanic materials such as volcano ash to the lime mortars to create hydraulic mortars for the purpose of building aqueducts, cistern, fish pond etc [4]. Basic characteristics of pozzolan are able to react with lime and able to form insoluble products with binding properties, in other words pozzolan is all inorganic substances that harden in the water when combine with calcium hydroxide or material that produce calcium hydroxide $[5,6]$.

In the $18^{\text {th }}$ century, it was discovered that burning limestone containing clay would produce hydraulic lime that will exhibit hydraulic properties once introduced to water. An Italian pozzolanic earth was added to provide better performance in strength [7]. Roman cement also known as natural cement was patented by James Parker in 1796 which produced from burning limestone and clay together in the kiln. Naturally, this kind of cement contains higher clay content than hydraulic lime and used where the construction subjected to moisture and required high level of strength [2].

Portland cement (PC) was patented by Joseph Aspdin in 1824. The earlier PC was produced by blending limestone, clay and other minerals in carefully controlled proportion 
through calcinations process and grounded to fine particles. Higher level of strength and consistency in PC finally replace the used of natural cement. PC by itself had poor workability, but combining it with pozzolanic materials provides an excellence balance between strength and workability. Also adding lime to $\mathrm{PC}$, that create pozzolanic cement showed higher resistance to aggressive agent [6].

\section{LIME PROPERTIES}

Generally, lime is classified based on its ability to set under water, which are called hydraulic lime and nonhydraulic lime. This classification system was formally first introduced by Louis Vicat, a well known French engineer whose works were published between 1830s and 1840s. Non-hydraulic lime takes time to set as compared to hydraulic lime when used in construction. Non-hydraulic lime is derived from the calcinations process of pure limestone whilst the hydraulic lime is from the limestone that contains clay and other impurities.

The properties of hydraulic lime setting under water are coming from silica and clay in the limestone. When limestone is burnt between $400^{\circ} \mathrm{C}$ to $600^{\circ} \mathrm{C}$, the clay decomposed. The decomposed clay combines with silica between $950^{\circ} \mathrm{C}$ to $1250^{\circ} \mathrm{C}$. During the sintering process which takes place at $1300^{\circ} \mathrm{C}$ to $1400^{\circ} \mathrm{C}$ resulted in the formation of silicates and aluminates especially tricalcium silicates $\left(\mathrm{C}_{3} \mathrm{~S}\right)$ and dicalcium aluminate $\left(\mathrm{C}_{2} \mathrm{~A}\right)$ [8].

Hydraulic lime differs from hydrated lime from the way its work. Hydrated lime when added with water will have very thick consistency characteristic. However, hydraulic lime will begin to harden once exposed to water. And after that, it will absorb carbon dioxide from the air to experience a second phase of hardening or curing. Hydraulic lime offers a number of benefits over traditional lime mortar blends. The most important is its ability to cure and harden when wet, this means it can be used in many applications where other mortar products would fail. It also has low elasticity, resulting in fewer cracks due to expansion and contraction. Hydraulic lime is also very porous, allowing excess moisture to escape rather than collecting inside the wall structure. This makes it very popular for historic preservation applications, where traditional hydrated lime would crack or crumble over time due to trapped moisture.

Lime $\left[\mathrm{Ca}(\mathrm{OH})_{2}\right]$ is produced by hydrating quicklime $(\mathrm{CaO})$. Quicklime is resulted from heating of lime stone $\left(\mathrm{CaCO}_{3}\right)$ and the process is known as calcinations with endothermic characteristic [9] as shown by the chemical equation below:

$$
\begin{aligned}
\mathrm{CaCO}_{3} \text { (heating) } \rightarrow \mathrm{CaO}+\mathrm{CO}_{2} \\
\Delta \mathrm{H}=+182.1 \mathrm{~kJ} \mathrm{~mol}^{-1}
\end{aligned}
$$

When quicklime is added with water it is called slaked lime (and becomes hot and cracks to form a white powder). This process is called slaking of lime.

$$
\mathrm{CaO}+\mathrm{H}_{2} \mathrm{O} \rightarrow \mathrm{Ca}(\mathrm{OH})_{2}+\text { heat } \uparrow
$$

When calcium hydroxide exposed to carbon dioxide it will produce materials that hardens more quickly rather than slaked lime. But still it takes years to complete the reaction.
The product also very porous which will be the advantage of lime for it's allow building to breathe and resulted in less moisture trapped inside the building which is not good for the health of the occupants.

$$
\mathrm{Ca}(\mathrm{OH})_{2}+\mathrm{CO}_{2} \rightarrow \mathrm{CaCO}_{3}+\mathrm{H}_{2} \mathrm{O} \uparrow
$$

When carbon dioxide $\left(\mathrm{CO}_{2}\right)$ is introduced back into quicklime, it will revert back into limestone. This reverse process called by carbonation and it is exothermic.

$$
\begin{array}{r}
\mathrm{CaO}+\mathrm{CO}_{2} \rightarrow \underset{\Delta \mathrm{CaCO}+\text { heat }}{\mathrm{CH}_{3}-182.1 \mathrm{~kJ} \mathrm{~mol}^{-1}}
\end{array}
$$

This carbonation process is not useful (not reactive) and detrimental in soil stabilization process also during transportation and storage because quicklime (and also Portland cement) are not stable under normal environment and will hardened readily in the present of carbon dioxide. This can be avoided by protecting quicklime from the exposure of air. But its ability to absorb lime after the construction will be the benefit for lime.

Besides quicklime, lime also can be made from heating limestone containing magnesium carbonate $\left[\mathrm{CaMg}\left(\mathrm{CO}_{3}\right)_{2}\right]$ around $750^{\circ} \mathrm{C}$ and the product is called dolomitic quicklime.

$$
\mathrm{CaMg}\left(\mathrm{CO}_{3}\right)_{2} \text { (heating) } \rightarrow \mathrm{CaCO}_{3}+\mathrm{MgO}+\mathrm{CO}_{2}
$$

In simple words, heating limestone will produced quicklime, and adding it with water will produce lime hydrated. Hydrated lime is simply a form that lime can be supplied in, where hydraulic lime is the binding characteristic of the lime that can be harden with the present of water.

\section{LIME STABILIZATION}

In ancient Mesopotamia, Egypt, Greeks and Roman, lime has a long history in earth road stabilization. Lime application can improve engineering properties in two ways which are stabilization and modification. Lime can modify all fine grain soil but most striking effect happened with clay soil of moderate to high plasticity [10]. Stabilization differs from modification in term of period where a strength gain is developed through pozzolanic reaction.

In soil stabilization, when lime is added to reactive soil it will produce stable calcium silicate hydrates and calcium aluminate hydrates as the calcium from the lime reacts with the silicates and aluminates solubilized from the clay and generate long term strength gain where the pozzolanic reaction can continue for a very long period of time, even decades as long as enough lime is present and the $\mathrm{pH}$ remains high (above 10).

Lime modification occurs primarily due to exchange of calcium cations supplied by the hydrated lime with the cations normally present on the surface of the clay mineral, promoted by the high $\mathrm{pH}$ environment of the lime-water system. 


\section{POZZOLANIC REACTION In LIME StABILIZATION}

According to Massazza, pozzolans have two significant meanings, the first is pointing to a kind of pyroclastic rock which usually occur around Pozzuoli or Rome. The second one, which more generally used in term of construction, is all inorganic materials, either natural or artificial that will harden in the water if combine with lime (calcium hydroxide) [6]. Basically, pozzolans have two fundamental characteristic that are able to react with lime and able to create insoluble product with binding properties [11].

Based on earlier researches and manuscripts, many engineering properties of clay soils are improved by the addition of lime. It is used in road, railroad, airport, embankments, retaining wall, improvement for the soil beneath slabs foundation and for lime piles $[12,13]$. Mostly occurs clay minerals are non expansive clay minerals like kaolinite, expansive clay (capable of absorbing water) minerals such as illite, montmorillonite and non clay mineral, quartz.

It is found that clay mineral exhibit high pozzolanic reactivity when burnt at temperature $600^{\circ} \mathrm{C}$ to $900^{\circ} \mathrm{C}$ and ground to cement-fine, where fundamental characteristic of pozzolan which mostly composed of silica and alumina usually defined as ability to react with lime and ability to form insoluble products with binding property [13].

$$
\begin{array}{ll}
\mathrm{CaO}+\mathrm{H}_{2} \mathrm{O} & \rightarrow \mathrm{Ca}(\mathrm{OH})_{2}+\text { heat } \uparrow \\
\mathrm{Ca}(\mathrm{OH})_{2}+\mathrm{H}_{4} \mathrm{SiO}_{4} & \rightarrow \mathrm{Ca}^{2+}+\mathrm{H}_{2} \mathrm{SiO}_{4}{ }^{2-}+2 \mathrm{H}_{2} \mathrm{O} \\
& \rightarrow \mathrm{CaH}_{2} \mathrm{SiO}_{4} \cdot 2 \mathrm{H}_{2} \mathrm{O}=\mathrm{CSH}
\end{array}
$$

When lime is added to clay soil, the reaction immediately occurs is cation exchange from the metallic ions related with clay particles with calcium ions of the lime. The ions exchange modified the clay particles so that surrounded by the diffuse hydrous double layer and resulted in increasing the density of electrical charge around the clay particles and take effect to the ions for being attracted closer to each other to form flocs, so this process being termed flocculation [14].

All types of clay react with lime but expandable clays such as montmorillonite usually react readily with lime and losing plasticity immediately, compare to that of non expansive clay like kaolinite $[10,15]$. When the exchange of ions occurs, ions from lime must first satisfy the affinity of the soil for lime, only after this affinity satisfied then the ions available for pozzolanic reaction. This terms is called as lime fixation since the lime is fixed in the soil [16]. Lime fixation point displayed that further addition of lime bring no further changes in the plastic limit and also show that this is the optimum lime addition for maximum modification of the soil. Beyond this point lime is available to increase the strength of the soil [10].

Besides cation exchange, there is another reaction occurs between silica and alumina of the clay minerals. Addition of lime provided highly alkaline environment and resulted in gave rise to the slow solution of alumino-silicates which are then precipitated as hydrated cementitious reaction products [17]. This reaction take time for strength to develop gradually and for maximum reactivity, the $\mathrm{pH}$ value of the pore fluids in the voids should stay around 12.4 [10]. Where pozzolanic activity can be measured by adding super saturated solution of calcium oxide to the pozzolan with water free from carbon dioxide at $40^{\circ} \mathrm{C}$ and determined the total alkalinity and calcium oxide content by the end of $8^{\text {th }}$ days $[11,18]$.

Hence, hypothetically, other sources of silica and alumina compound could be used as a source of pozzolanic materials for lime stabilization, such as fly ash, rice husk ash, POFA (palm oil fly ash), etc.

\section{LIME STABILIZED ClAy BRICKS}

Normal clay brick usually made by mix of clay, sand and water. As been described above, clay soil can be modified and enhanced its engineering properties by addition of lime. Where previous study had shown that ancient mortars made from hydrated lime and powdered bricks as a pozzolan, had proven excellent and lasted for centuries and being hydraulic [11]. Then the idea of making clay brick stabilized with lime and other sources of pozzolan is not a peculiar idea at all.

Conventional clay brick normally comprised clay in amount up to $95 \%$ and sand $5 \%$ of total composition. The expectation of making brick with lime as stabilizer and the present of pozzolanic materials from clay it self could make the brick has better properties especially in strength and durability. Also utilizing other source of pozzolanic materials as the additional ingredients to the mix has a very big possibility.

For fired clay bricks, lime as a stabilizer could react very well under firing temperature between $600^{\circ} \mathrm{C}$ to $900^{\circ} \mathrm{C}$ and produce higher strength brick compare to that of normal clay brick. Osula [19] reported that lime seems twice as effective as cement at $1 \%$ modifier content and strengthen hypothesis that claimed lime is a better modifier than cement for soils that have appreciable clay content, even for soil with low clay content like laterite soil.

Previous works by Oti et al [20-22] on unfired clay brick utilizing high organic and sulphate content successfully convinced that lime especially quicklime have benefits in enhancing properties and overall durability of stabilized clay system. Furthermore, promoting the use of unfired clay brick could contribute to the environmental improvement since the emission of carbon dioxide from firing process could be omitted.

Lime modification showed rapid initial increase in strength for montmorillonite clay and exhibit earlier gain in strength but for further ageing, additional strength achieved by kaolinitic clay is better. Additional of fine quartz to the mix apparently could increase the strength significantly [10]. The reaction between lime and pozzolanic materials usually slow and accelerated strength gain can be attained by autoclaving or low pressure steam curing [23].

As for unfired compressed earth brick that normally used cement as stabilizer, substituting cement with lime show great possibility from what the previous research have found. Combination of clay soil, lime, sand, water and addition pozzolan such as fly ash, slag, gypsum, rice husk ash or POFA will produced hydraulic material that will harden through age. 


\section{CONCLUSIONS}

From the previous researches that have been elaborated above, some concluding remarks can be drawn i.e.:

- Hydraulic properties of lime basically coming from silica and clay from limestone.

- Lime-clay mix showed pozzolanic reactivity when added with water which hydraulic properties depend on.

- Clay showed high pozzolanic reactivity when burnt at temperature $600^{\circ} \mathrm{C}$ to $900^{\circ} \mathrm{C}$.

- Lime modification to expansive clay resulting on decreasing plasticity because the high ability of clay to absorb water.

- Lime has excellent properties in modifying soil not only with appreciable clay content but with the soil with low clay content.

- Important aspect of lime-soil modification is fine grain size.

- The use of lime is support green environment since it has less embodied energy than cement plus free lime absorb carbon dioxide in the setting process of carbonation.

For further research could explore the possibility of mixing lime with other sources of silica and alumina from waste material to produce pozzolanic properties at low cost and environmental friendly.

\section{ACKNOWLEDGMENT}

The authors would like to thank the Universiti Tun Hussein Onn (UTHM), Johor, Malaysia for providing the international student scholarship and finally acknowledge the research and staffing resources provided by the Faculty of Civil and Environment of the Universiti Tun Hussein Onn (UTHM).

\section{REFERENCES}

[1] Boynton, R.S., Chemistry and Technology of Lime and Limestone. Second ed. 1980, New York: John Wiley \& Sons, Inc.

[2] McKee, H.J., Introduction to Early American Masonry - Stone, Brick, Mortar, and Plaster. 1973: National Trust for Historic Preservation, Columbia University. 61.
[3] Vitruvius, De Architectura. 1931, Heinemann.

[4] Davey, N., A History of Building Materials 1971, New York: Drake Publishers Ltd.

[5] Massazza, F., Chemistry of Pozzolanic Addition and Mixed Cements. Il Cemento, 1976. 73(1): p. 3-28.

[6] Massaza, F., Pozzolanic cements. Cement and Concrete Composites, 1993. 15(4): p. 185-214.

[7] Cowper, A.D., Lime and Lime Mortars. Building Research Station, 1927, London: HM Stationery.

[8] Ashurst, J., The Technology and Use of Hydraulic Lime. 1997. http://www.buildingconservation.com/articles/hydraulic/hydraulic.htm

[9] Stanmore, B.R. and P. Gilot, Review - calcination and carbonation of limestone during thermal cycling for $\mathrm{CO} 2$ sequestration. Elsevier-Fuel Processing Technology, 2005(86): p. 1707-1743.

[10] Bell, F.G., Lime stabilization of clay minerals and soils. Engineering Geology, 1996. 42(4): p. 223-237.

[11] Baronio, G. and L. Binda, Study of the pozzolanicity of some bricks and clays. Construction and Building Materials, 1997. 11(1): p. 41-46.

[12] Anon, Lime Stabilization Construction Manual. National Lime Association. 1985, Arlington, VA: Eight Edition

[13] Anon, Lime Stabilization Manual. British Aggregate Construction Materials Industry. 1990, London.

[14] Sherwood, P.T., Soil Stabilization with Cement and Lime: State of the Art Review. TRansport Research Laboratory, Her Majesty's Stationery Office. 1993, London.

[15] Bell, F.G. and J.M. Coulthard, Stabilization of clay soils with lime. Mun. Engr, 1990. 7.

[16] Hilt, G.H. and D.T. Davidson, Lime fixation of clayey soils. High. Res. Board, Bulletin. 1960, Washington D.C. 20-32.

[17] Diamond, S. and E.B. Kinter, Adsorption of calcium hydroxide by montmorillonite and kaolinite. Colloid Interface Science, 1966. 22: p. 240-249.

[18] Malquori, G. Portland-pozzolan cement. in Fourth International Symposium Chemistry of Cement. 1960. Washington.

[19] Osula, D.O.A., A comparative evaluation of cement and lime modification of laterite. Engineering Geology, 1996. 42(1): p. 71-81.

[20] Oti, J.E., J.M. Kinuthia, and J. Bai, Engineering properties of unfired clay masonry bricks. Engineering Geology, 2009. 107(3-4): p. 130139.

[21] Oti, J.E., J.M. Kinuthia, and J. Bai, Compressive strength and microstructural analysis of unfired clay masonry bricks. Engineering Geology, 2009. 109(3-4): p. 230-240.

[22] Oti, J.E., J.M. Kinuthia, and J. Bai, Design thermal values for unfired clay bricks. Materials \& Design, 2009. 31(1): p. 104-112.

[23] Cook, D.J., R.P. Pama, and B.K. Paul, Rice Husk Ash-Lime-Cement Mixes for Use in Masonry Units. Building and Environment, 1977. 12: p. 281-288. 